\title{
Selection indexes for genetic improvement of yearling weight in Egyptian buffaloes
}

\author{
KARIMA A. SHAHIN', OMAR Y. ABDALLAH', TAREK A. FOODA², and KAWTHER A. \\ MOURAD
}

'Department of Animal Production, Faculty of Agriculture, Ain Shams University, Cairo, Egypt, ${ }^{2}$ Department of Buffalo Breeding, Animal Production Research Institute, Cairo, Egypt

\begin{abstract}
Estimates of genetic and phenotypic parameters for body weight at birth, 3, 6, 9, and 12 months of age, and for preweaning and postweaning average daily gain were computed and used to construct 14 selection indexes to improve the 12-month weight in Egyptian buffaloes. The full index incorporating body weight at birth, 3, 6, 9 and 12 months of age had the highest correlation with aggregate breeding value $\left(r_{\mathrm{TI}}=0.63\right)$. The correlation fell to 0.62 when body weight at birth and 3 months were omitted from the index. Selection for body weight at 12 months of age alone is expected to be $76.2 \%$ as efficient as selection for the full index.

The maximum expected genetic gain in 12-month body weight was $8.85 \mathrm{~kg} /$ generation when all five body weights were included in the index; this decreased to $8.09 \mathrm{~kg} / \mathrm{generation}$ when body weights at birth, 3 and 6 months were excluded and further decreased to $6.94 \mathrm{~kg} /$ generation when selection based on yearling weight only. From the practical standpoint, selection on $\mathrm{I}_{5}$ involving body weight at 9 month of age can be considered as the best for improving body weight at 12 month since its application is earlier, less expensive, higher accuracy than any index excluding body weight at 12 month and giving reasonable amount (+5.39 kg) improvement in yearling weight as compared to direct selection (+6.94 kg).
\end{abstract}

Keywords: Egyptian buffaloes, yearling body weight, daily gain, phenotypic and genetic parameters, heritability, selection indexes

\section{Zusammenfassung}

\section{Züchterische Verbesserung der Jährlingsgewichte bei Ägyptischen Büffeln mittels Selektionsindizes}

Es wurden genetische und phänotypische Parameter für Geburts-, 3-, 6-, 9- und 12-Monatsgewichte sowie der täglichen Zunahmen Ägyptischer Büffel ermittelt und für die Konstruktion von 14 Selektionsindizes zur Erhöhung der 12-Monatsgewichte genutzt. Der Gesamtindex, welcher die Gewichte aller Altersetappen enthielt, zeigte die größte Beziehung zum Gesamtzuchtwert. $\left(r_{\mathrm{Ti}}=0,63\right)$. Dieser Wert verringerte sich auf 0,62, wenn die Werte für Geburts- und 3-Monatsgewicht nicht einbezogen wurden. Das 12-Monatsgewicht allein zeigt mit 76,2\% einen höheren Erwartungswert als der Gesamtindex. Das Maximum des erwarteten genetischen 12-Monate-Gewichtszuwachses 
von $8,85 \mathrm{~kg}$ je Generation wurde erreicht, wenn alle fünf Körpergewichte einbezogen wurden. Es verringerte sich auf 8,09 kg/Generation, wenn Geburts-, 3- und 6-Monatsgewichte genutzt wurden, und auf $6,94 \mathrm{~kg} / \mathrm{Generation}$ bei Nutzung des Jährlingsgewichts allein. Nach praktischen Erwägungen erwies sich der $I_{5^{\prime}}$ d.h. die Einbeziehung des 9-Monatsgewichtes als der effektivste da er früher verfügbar, weniger teuer und genauer ist als wenn auch 12 Monatsgewichte einbezogen wurden. Die einfachere Erfassbarkeit von $I_{5}$ erreicht mit $+5,39 \mathrm{~kg} /$ Generation brauchbare Zuwächse gegenüber einer direkten Selektion nach den Jährlingsgewichten $(+6,94 \mathrm{~kg} / \mathrm{G})$.

Schlüsselwörter: Ägyptische Büffel, Jährlingsgewichte, tägliche Zunahmen, phänotypische Parameter, genetische Parameter, Heritabilität, Selektionsindizes

\section{Introduction}

The buffaloes are nearly equal in number to Egypt's native cattle (c. $3.5 \mathrm{~m}$ vs. $3.6 \mathrm{~m}$ ). They are used as the main sources of red meat and milk. Little efforts have been made to improve their genetic potentiality for meat production and they suffer limited literature on genetic parameters of growth-related traits with no available reports on use of selection to improve their growth characteristics. MOURAD and KHATTAB (2009) constructed selection indexes for improving some productive traits in Egyptian buffaloes and BHAT (1992), AMIN (2003), SENO et al. (2006), KHAN et al. (2007) and KUMAR et al. (2008) discussed breeding strategies for production of buffaloes for milk production. Studies on cattle have shown that yearling weight is a highly heritable character and positively phenotypically and genetically correlated with other weights at either ends of growth curve which would indicate that this weight could be changed genetically by selection (ATIL et al. 2005). Yearling weight may be viewed as a simple form of a selection index combining birth weight, weaning weight and post-weaning gain. Buffalo growth around 12 month of age is directed towards muscling and away from fatness, a characteristic which is appreciated by Egyptian consumers. In Egypt, rearing buffalo males intended for meat production has rationally been and will continue to be performed at 12 months as demonstrated by the success of the Egyptian national project for rearing/fattening buffalo calves "Beetello«. Improvement of performance traits in multiple traits simultaneously is an increasing important breeding goal in buffalo and other livestock species (SHAHIN et al. 2000a, b). Selection index is an objective method of selection for a linear function of several traits at once which summarize overall genetic merit. The objective of this study were to estimate the genetic and phenotypic parameters for growth traits, to incorporate these estimates in construction selection indexes for improving 12 month weight in Egyptian buffaloes and to calculate genetic responses for selection.

\section{Material and methods}

\section{Source of data and animal management}

The data were collected on 244 buffalo calves (148 females and 96 males) from 192 buffalo cows sired by 27 bulls that had complete information and their sires having 5 progeny and 
more. Animals were maintained at El-Nattafe El-Gidid and El-Nattafe El-Kadim Experimental Stations (Mahalet Mousa in Kafr El-Sheikh Governorate, in the Delta region, Egypt) belonging to Animal Production Research Institute, Ministry of Agriculture. The Egyptian buffaloes are grey-black in colour with short curved horns, the weight of adult male is $600 \mathrm{~kg}$, and for the adult female is $500 \mathrm{~kg}$. The Egyptian buffalo males possess outstanding beef type body conformation. The newborn calves were fed 7 days with the dam's colostrums then they were fed twice daily on fresh milk and weaned at 105 day of age or $100 \mathrm{~kg}$ live body weight. After weaning, calves were fed according to the prevailing nutritional regime for beef production in Egypt: $1 \mathrm{~kg}$ concentrates plus $0.50 \mathrm{~kg}$ dry roughages per $50 \mathrm{~kg}$ live body weight.

\section{Traits considered}

Birth weight and body weights at 3 month intervals to 12 months were recorded. They were furthermore used to obtain alternative growth traits, namely pre-wean average daily gain, and wean to 12 months daily gain "post-weaning average daily gain«.

\section{Statistical analyses}

Estimates of variance components for traits in this study were obtained using least squares and maximum likelihood program (HARVEY 1990), according to the following model:

$$
Y_{i j k l m}=\mu+S_{i}+A_{j}+X_{k}+O_{l}+(A X)_{j k}+(X O)_{k l}+e_{i j k l m}
$$

where $Y_{i j k l m}$ is the observation on the $m$-th animal of the $i$-th sire, $j$-th year of calving, $k$-th sex of calving and $l$-th season of calving, $\mu$ is the Overall mean, $S_{i}$ is the Random effect of sire, $(i=1,2, \ldots, 27), A_{j}$ is the fixed effect due to year of calving, $(j=1,2, \ldots, 6), X_{k}$ is the Fixed effect due to sex of calf, $(k=1,2)$ where $1=$ male and $2=$ female, $O$, is the Fixed effect due to season of calving, $(I=1,2,3,4)$ where $1=$ winter, $2=$ spring, $3=$ summer and $4=$ autumn, $(A X)_{j k}$ is the interaction between year of calving and sex of calf, $(X O)_{k l}$ is the interaction between sex of calf and season of calving and $e_{i j k l m}$ is the random error assumed N.I.D. $\left(0, \sigma_{\mathrm{e}}^{2}\right)$.

Selection indexes for different combinations of growth-related traits were calculated using the parameters estimated in this study. The economic values for 6,9 and 12 month weights in the present study were assumed to the price of $1 \mathrm{~kg}$ for meat at ages 6,9 and 12 month were 10, 9 and 8 Egyptian pound, respectively. Therefore the relative economic value for 6,9 and 12 month weight in this study were 1.25, 1.13 and 1 respectively. The selection index equations (I) were defined (CUNNINGHAM and MAHOU [1977]) as:

$$
\begin{aligned}
& \text { Index: } I=\sum_{i=1}^{m} b_{i} P_{i}=\underline{b}^{`} \underline{\underline{p}} \\
& \text { Aggregate genotypes value: } H=\sum_{\mathrm{i}=1}^{n} a_{i} g_{i}=g^{\prime} \underline{a}
\end{aligned}
$$

index weight: $\underline{b}=p^{-1} G \underline{a}$ 
where $\underline{b}^{\prime}$ is a row vector of $m$ index coefficients, $\underline{p^{\prime}}$ is a vector of $m$ known phenotypic observations, $\mathrm{g}$ 'is a row vector of $\mathbf{n}$ unknown genetic effects, a ' is a row vector of $\mathbf{n}$ known relative economic values, $P$ is the phenotypic variance-covariance matrix $(m \times m)$ and $G$ is generic variance-covariance matrix $(m \times n)$.

The expected genetic change after one round of selection for any of the traits considered in selection is calculated as

$$
\begin{aligned}
& \Delta G_{i}=r_{G_{i} l} \cdot i \sigma_{G_{i}} \\
& \Delta G_{i}=b_{G_{i} l} \cdot i \sigma_{l}
\end{aligned}
$$

where $\Delta G_{i}$ is the Expected genetic change for the ith trait expressed in absolute units/ generation $(i=1,2, \ldots 7), i$ is the Intensity of selection (assumed $i=1), r_{G_{i}}$ is Correlation of the trait with index and $b_{G_{j} l}$ is the Regression of the trait on the index.

\section{Results}

Means, genetic and phenotypic coefficients of variation and heritabilities

Table 1 presents the averages, genetic and phenotypic coefficients of variation and heritability estimates for body weight at various ages and pre- and post-weaning average daily gain. Body weight at 12 months of age averaged $179 \mathrm{~kg}$ and ranged from 101 to $275 \mathrm{~kg}$.

The coefficient of phenotypic and genetic variability increased with advancing of age from 3 to 9 months. The phenotypic and genetic coefficient of variability for average daily gain (ADG) 3-12 was higher than that for ADG 0-3 (6.58 vs. $5.10 \%$ and 6.18 vs. $0.82 \%$ ).

Table 1

Trait averages, heritability estimates and genetic and phenotypic coefficients of variation Merkmalsmittelwerte, Heritabilität, Schätzwerte der genetischen und phänotypischen Variationskoeffizienten

\begin{tabular}{lcccc}
\hline & \multicolumn{4}{c}{ Coefficients of variation } \\
Trait & Mean (kg) & Phenotypic & Genetic & Heritability Estimates \\
\hline Body weight at: & & & & \\
Birth (W0) & 33.50 & 4.42 & 3.10 & 0.49 \\
3-month (W3) & 77.28 & 3.75 & 1.20 & 0.10 \\
6-month (W6) & 113.95 & 3.87 & 2.58 & 0.44 \\
9-month (W9) & 148.05 & 4.30 & 3.57 & 0.69 \\
12-month (W12) & 179.01 & 4.10 & 3.99 & 0.95 \\
Average daily gain (kg/day) in age periods: & & & \\
Pre-weaning (ADG 0-3) & 0.49 & 5.10 & 0.82 & 0.02 \\
Post-weaning (ADG 3-12) & 0.38 & 6.58 & 6.18 & 0.89 \\
\hline
\end{tabular}

W0 birth, W3 3 month, W6 6 month, W9 9 month, W12 12 month

The heritability estimates for body weight at various ages increased with age of calves from 0.10 at 3 months to 0.95 at 12 months. The heritability estimate of birth weight was higher than that of body weight at 3 months of age and the heritability estimate of post-weaning average daily gain was higher than that for pre-weaning average daily gain. 


\section{Genetic and phenotypic correlations}

Table 2 gives the genetic and Phenotypic correlations between growth performance traits. As a general trend, after weaning the genetic correlation coefficients among body weights at various ages were positive and high. Most of the phenotypic correlations were generally lower than their genetic counterparts. The genetic correlation between yearling weight with body weights at 3, 6 and 9 months of age were positive and high $(>0.90)$.

Table 2

Genetic (below diagonal) and phenotypic (above diagonal) correlations among growth - related traits in Egyptian buffaloes

Genetische (unter) und phänotypische (über Diagonale) Korrelationen der Wachstumsmerkmale

\begin{tabular}{lllllllr}
\hline & W0 & W3 & W6 & W9 & W12 & ADG 0-3 & ADG 3-12 \\
\hline W0 & - & 0.35 & 0.23 & 0.19 & 0.15 & -0.26 & 0.05 \\
W3 & 0.97 & - & 0.49 & 0.35 & 0.29 & 0.81 & -0.02 \\
W6 & 0.18 & 0.98 & - & 0.68 & 0.60 & 0.36 & 0.49 \\
W9 & -0.06 & 0.89 & 0.96 & - & 0.82 & 0.25 & 0.75 \\
W12 & 0.09 & 0.96 & 0.97 & 0.91 & - & 0.20 & 0.94 \\
ADG 0-3 & -0.97 & -0.98 & 0.99 & 0.99 & 0.98 & - & -0.05 \\
ADG 3-12 & -0.01 & 0.86 & 0.97 & 0.94 & 0.99 & 0.99 & - \\
\hline
\end{tabular}

W0 birth, W3 3 month, W6 6 month, W9 9 month, W12 12 month

\section{Selection indexes}

The estimates of genetic and phenotypic parameters calculated in the present study were used to construct 14 indices. Table 3 gives the weighing factors (b-values) representing the partial or simple regressions of genetic value for net merit on phenotype for each trait, standard deviation $\left(\sigma_{1}\right)$, accuracy of selection $\left(r_{T}\right)$ representing the multiple or simple correlation of selection index with genetic value for net merit and relative efficiency (RE).

It appears that the maximum accuracy of selection $\left(r_{\mathrm{T}}=0.63\right)$ was obtained using the full index. This magnitude of accuracy did not essentially change $\left(r_{T 1}=0.62\right)$ when W0 and W3 were ignored from the full index but the accuracy was decreased $\left(r_{T I}=0.58\right)$ when W6 was also ignored from the full index. Comparing the three indexes $\mathrm{I}_{4}=0.724 \mathrm{~W} 6, \mathrm{I}_{5}=0.512 \mathrm{~W} 9$ and $\mathrm{I}_{6}=0.537 \mathrm{~W} 12$ selection for $\mathrm{W} 12$ alone would be more efficient $\left(\mathrm{r}_{\mathrm{Tl}}=0.48\right)$ than selection for $\mathrm{W} 9$ $\left(r_{\mathrm{TI}}=0.40\right)$ alone or $\mathrm{W6}\left(\mathrm{r}_{\mathrm{TI}}=0.35\right)$ alone.

The accuracy values were comparable for the index including $W 12$ alone and the indexes combining W12 with ADG 0-3 $\left(\mathrm{I}_{12}: \mathrm{r}_{\mathrm{TI}}=0.48\right)$ or with ADG 3-12 $\left(\mathrm{I}_{13}: \mathrm{r}_{\mathrm{TI}}=0.49\right)$ or with ADG 0-3 and ADG 3-12 $\left(\mathrm{I}_{14}: \mathrm{r}_{\mathrm{TI}}=0.50\right)$. 
Table 3

Weighing factors (b-values), standard deviation ( $\sigma \mathrm{l})$, efficiencies of selection in absolutes $\left(\mathrm{r}_{\mathrm{T}}\right)$ and relative (RE) values in indexes used to improve body weight at 12 month

Wichtungsfaktoren, Standardabweichung sowie Effizienz der Indizes (absolut - $r_{T I}$ und relativ - RE) für eine Erhöhung der Jährlingsgewichte

\begin{tabular}{lllllllllllr}
\hline $\begin{array}{l}\text { Index } \\
\text { No. }\end{array}$ & $\begin{array}{l}\text { Source of } \\
\text { Information }\end{array}$ & W0 & W3 & W6 & W9 & W12 & ADG0-3 & ADG3-12 & $\sigma_{\text {I }}$ & r $_{\text {T1 }}$ & RE \\
\hline 1 & W0, W3, W6, W9, W12 & 0.037 & 0.293 & 0.497 & 0.375 & 0.424 & - & - & 20.44 & 0.63 & 100.00 \\
2 & W0 & 0.103 & - & - & - & - & - & - & 0.57 & 0.02 & 3.17 \\
3 & W3 & - & 0.479 & - & - & - & - & - & 4.48 & 0.14 & 22.22 \\
4 & W6 & - & - & 0.724 & - & - & - & - & 11.35 & 0.35 & 55.56 \\
5 & W9 & - & - & - & 0.512 & - & - & - & 13.06 & 0.40 & 63.49 \\
6 & W12 & - & - & - & - & 0.537 & - & - & 15.61 & 0.48 & 76.19 \\
7 & W9, W12 & - & - & - & 0.413 & 0.470 & - & - & 18.72 & 0.58 & 92.06 \\
8 & W6, W9, W12 & - & - & 0.504 & 0.379 & 0.429 & - & - & 20.26 & 0.62 & 98.41 \\
9 & ADG 0-3 & - & - & - & - & - & 7.729 & - & 1.42 & 0.04 & 6.35 \\
10 & ADG 3-12 & - & - & - & - & - & - & 15.060 & 4.76 & 0.15 & 23.81 \\
11 & ADG 0-3, ADG 3-12 & - & - & - & - & - & -25.550 & 26.040 & 5.71 & 0.17 & 26.98 \\
12 & W12, ADG 0-3 & - & - & - & - & 0.536 & 4.989 & - & 15.64 & 0.48 & 76.19 \\
13 & W12, ADG 3-12 & - & - & - & - & 0.528 & - & 11.590 & 16.03 & 0.49 & 77.78 \\
14 & W12, ADG0-3, ADG3-12 & - & - & - & - & 0.525 & -21.724 & 20.943 & 16.25 & 0.50 & 79.37 \\
\hline
\end{tabular}

W0 birth, W3 3 month, W6 6 month, W9 9 month, W12 12 month

Results of the expected genetic changes per generation in body weight at various ages and average daily gain for each round of selection are shown in Table 4. Selection on full index $\left(I_{1}\right)$ gave the greatest improvement in $W 12(+8.85 \mathrm{~kg})$. The indexes involving one or two traits beside $W 12$ yielded comparable improvement $\left(\mathrm{I}_{8}:+8.77 \mathrm{~kg} ; \mathrm{I}_{7}:+8.09 \mathrm{~kg} ; \mathrm{I}_{14}:+7.14 \mathrm{~kg} ; \mathrm{I}_{13}\right.$ : $\left.+7.12 \mathrm{~kg} ; \mathrm{l}_{12}:+6.97 \mathrm{~kg}\right)$.

Table 4

Expected genetic changes per generation in body weights $(\mathrm{kg})$ and average daily gains ( $\mathrm{kg} /$ day) when using indexes to improve body weight at 12 month (intensity of selection=1.0)

Erwarteter jährlicher Zuwachs für Körpergewichte und tägliche Zunahmen bei Indexnutzung zur Erhöhung der Jährlingsgewichte (Selektionsintensität=1,0)

\begin{tabular}{clccccccc}
\hline & & \multicolumn{3}{c}{ Expected genetic gain } & \multicolumn{3}{c}{ in related traits } \\
$\begin{array}{l}\text { Index } \\
\text { no. }\end{array}$ & Source of & Information & in the trait in aggregate genotype & W12 & W0 & W3 & ADG 0-3 & ADG 3-12 \\
\hline 1 & W0, W3, W6, W9, W12 & 3.467 & 6.421 & 8.851 & 0.109 & 0.837 & 0.005 & 0.029 \\
2 & W0 & 0.261 & -0.184 & 0.457 & 0.725 & 0.396 & -0.004 & 0.002 \\
3 & W3 & 0.804 & 1.343 & 1.954 & 0.237 & 0.310 & -0.001 & 0.005 \\
4 & W6 & 1.939 & 3.526 & 4.940 & 0.093 & 0.480 & 0.004 & 0.016 \\
5 & W9 & 2.167 & 4.389 & 5.387 & -0.041 & 0.492 & 0.006 & 0.019 \\
6 & W12 & 2.663 & 4.725 & 6.941 & 0.088 & 0.628 & 0.006 & 0.023 \\
7 & W9, W12 & 3.161 & 5.913 & 8.091 & 0.041 & 0.735 & 0.008 & 0.027 \\
8 & W6, W9, W12 & 3.428 & 6.375 & 8.767 & 0.071 & 0.808 & 0.005 & 0.029 \\
9 & ADG 0-3 & 0.359 & 0.821 & 0.937 & -0.117 & -0.038 & 0.129 & 0.234 \\
10 & ADG 3-12 & 0.798 & 1.492 & 2.078 & 0.029 & 0.161 & 0.136 & 0.188 \\
11 & ADG 0-3, ADG 3-12 & 1.446 & 1.479 & 2.228 & 0.137 & 0.201 & 0.090 & 0.079 \\
12 & W12, ADG 0-3 & 2.632 & 4.756 & 6.971 & 0.081 & 0.628 & 0.013 & 0.036 \\
13 & W12, ADG 3-12 & 2.732 & 4.864 & 7.119 & 0.091 & 0.638 & 0.037 & 0.065 \\
14 & W12, ADG0-3, ADG3-12 & 2.914 & 4.844 & 7.135 & 0.123 & 0.646 & 0.029 & 0.040 \\
\hline
\end{tabular}

W0 birth, W3 3 month, W6 6 month, W9 9 month, W12 12 month 


\section{Discussion}

The moderate to high estimates of heritability for body weight at various ages other than at 3 months of age reported in this study indicated good prospects for improvement of these live performance traits through selection if these animals are uniformly managed and fed.

The heritability estimate for birth weight as considered in the present study was higher than those reported by other workers (ALIM 1991, MAHDY et al. 1999, MOURAD and KHATTAB, 2009 for Egyptian buffaloes), and was lower than estimates reported by THEVAMANOHARAN et al. (2001) for Thailand buffaloes, CHAKRAVARTY and RATHI (1989a) and TIEN and TRIPATHI (1990) for Indian buffaloes. MURDIA and CHAUDHARY (1984) found the $h^{2}$ estimate for birth weight in Indian buffaloes was -0.02 . This small and negative estimate may be attributed to sampling error or genotype-environmental interactions and other factors.

The heritability estimate for body weight at 3 months of age in the present study was much lower than that reported by GURUNG and JOHAR (1983) for Murrah buffaloes, THEVAMANOHARAN et al. (2001) for Thailand buffaloes and was similar to that reported by ANGULO et al. (2006) for the buffalo in the Colombia $\left(h^{2}=0.10\right.$, Egyptian buffaloes vs. $h^{2}=0.47$ for Murrah buffaloes and $\mathrm{h}^{2}=0.49,0.86$ for Thailand buffaloes). The discrepancy between these estimate may be attributed to different breeds of buffaloes. The low estimate of heritability for this trait suggested that most of the observed variation in this trait was due to temporary environmental conditions and management. Possibly, good management and feeding lead to much improvement for this trait.

The heritability estimate for body weight at 6 months of age as estimated in the present study was similar to the results of CKAKRAVARTY and RATHI (1989a) $\left(h^{2}=0.44\right.$, Egyptian buffaloes vs. 0.45 for Indian buffaloes) and slightly lower than that reported by DAHAMA and MALIK (1989) for Indian buffaloes $\left(h^{2}=0.50\right)$. TIEN and TRIPATHI (1990) working with Murrah buffalo heifers estimated the heritability of body weight at 6 months of age as 0.342 .

The heritability estimate for body weight at 12 months of age in the present study was high, indicating response to selection for this trait. This result is in agreement with those cited in the literature. (DAHAMA and MALIK 1989). Other workers (CKAKRAVARTY and RATHI 1989a and TIEN and TRIPATHI 1990) reported lower heritability estimates for yearling weight than that reported in this study.

The genetic inter-age correlations for weights were higher than the phenotypic. The phenotypic correlations of birth weight with subsequent weights found in the present study fall within the estimates reported by BONDOS et al. (1995) for buffaloes and SHEHU et al. (2008) for Sokoto Gudali cattle. Genetic correlations of weaning weight with subsequent weights at 6,9 and 12 months were $0.98,0.89$ and 0.96 , respectively; those of yearling weight with weights at 3, 6 and 9 months were $0.96,0.97$ and 0.91, respectively (Figure 1). The correlation of yearling weight with post-weaning average daily gain was close to one. These trend are in agreement with those of MAHDY et al. (1999) in Egyptian buffaloes and KUMAR et al. (1995) and PREETI and CHAKRAVARTY (1999) in Indian buffaloes. The magnitude of these correlations indicates that many of the genes that control yearling weight also control the early growth-related traits in the same direction. The positive genetic association between yearling weight with each of birth weight, pre-weaning gain, post-weaning gain suggested that selection to increase yearling weight would also cause some increase in the other traits. 


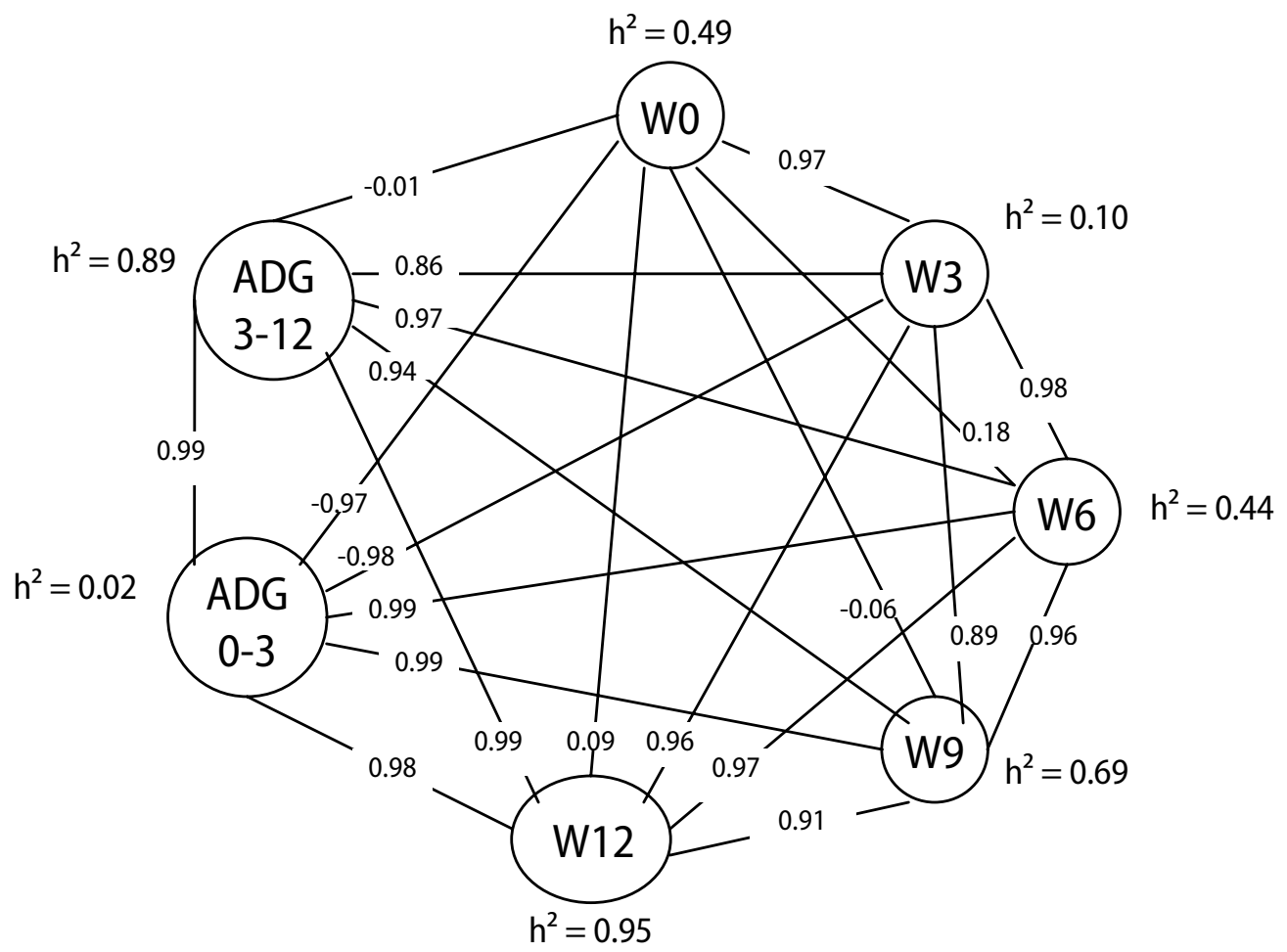

Figure 1

Heritabilities and genetic correlations for growth-related traits in Egyptian buffaloes Heritabilitäten und genetische Korrelationen bei Wachstumsmerkmalen Ägyptischer Büffel

To the authors' knowledge, no selection indexes are available to select for yearling weight or any other weights in Egyptian buffaloes. Few are available in the literature on improving genetic value of Indian buffaloes. CHAKRAVARTY and RATHI (1990a) constructed partial restriction selection index for genetic improvement of Indian buffaloes. They found that the best index was that which utilized weights at 12, 18 months, age at 1st calving and 1 st lactation milk yield. Selection on a restricted index with a partial restriction on W18 resulted in $67 \mathrm{~kg}$ more milk per generation than selection on the unrestricted index.

CHAKRAVARTY and RATHI (1990b) constructed unrestricting selection index for genetic improvement of Indian buffaloes. They found that compared with direct selection, an index comprising birth weight and 18 month weight was the best for improving adult weight.

CHAKRAVARTY et al. (1991) constructed several selection indices for the genetic improvement of Indian buffaloes. They found that the correlation between the index and the breeding value for aggregate genetic merit was highest for indices incorporating (1) W0, W6, W12 and W18 and (2) age at 1st calving, 1st service period and 300-day milk yield.

It appears from the limited literature given in this section the scarcity of reports investigating the possibility of improving buffalo's growth-related traits through use of selection indexes. The present study showed that, the full index incorporating body weight at birth, 3, 6, 9 and 12 months of age had the highest correlation with aggregate breeding 
value $\left(r_{\mathrm{TI}}=0.63\right)$. The correlation fell to 0.62 when body weight at birth and 3 months were omitted from the index. Selection for body weight at 12 months of age alone is expected to be $76.2 \%$ as efficient as selection for the full index.
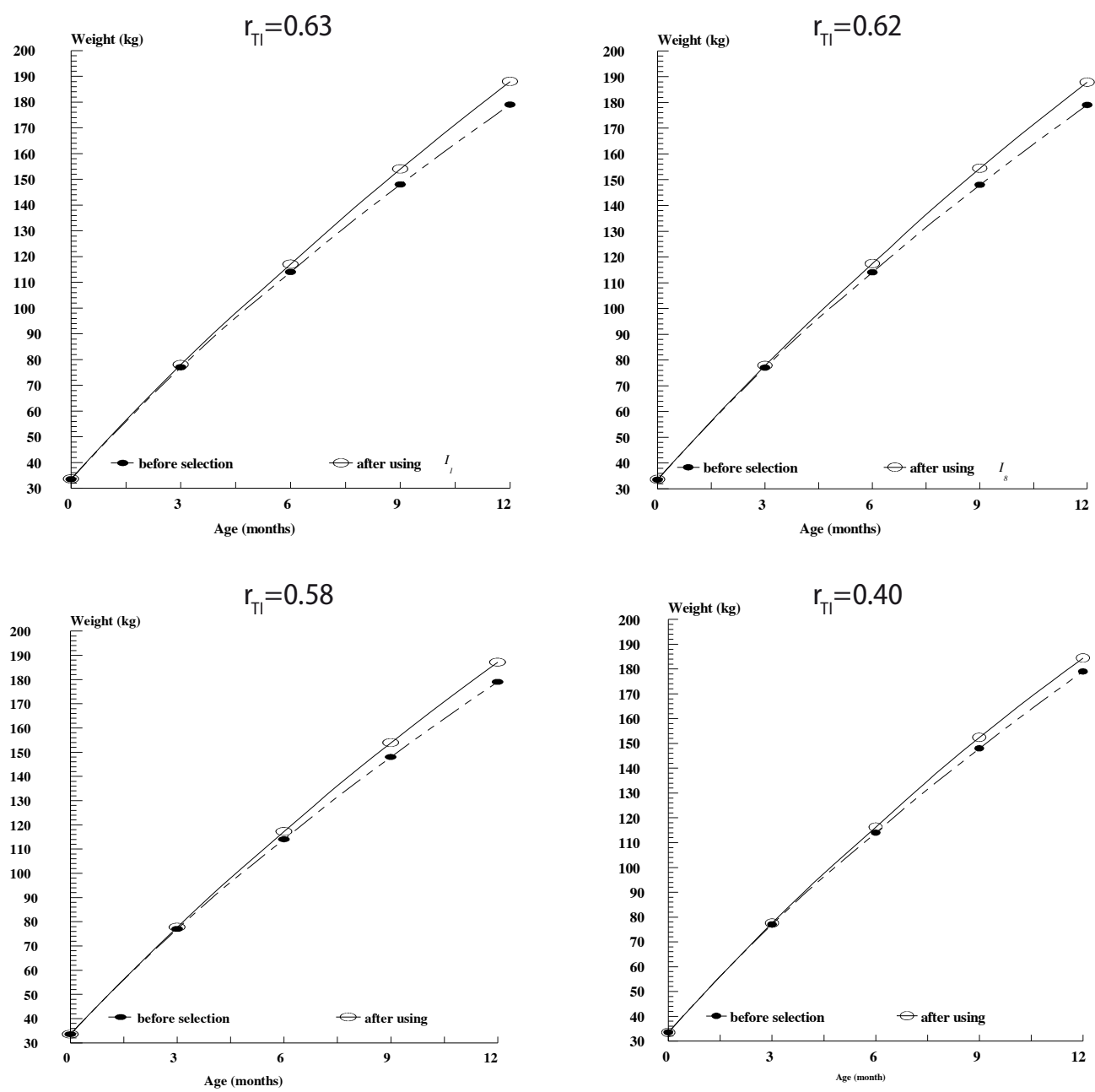

Figure 2

Expected body weights $(\ominus)$ after one round of selection on indexes $I_{1}, I_{8^{\prime}} I_{7}$ and $I_{5}$ compared with those of the original population (-)

Erwartete Körpergewichte bei Indexnutzung gegenüber Gewichten der Originalpopulation

Selection on single-trait indexes yielded progressive improvement in body weight at 12 months of age (selection on W0: $+0.46 \mathrm{~kg}$, on W3: $+1.95 \mathrm{~kg}$, on W6: $+4.94 \mathrm{~kg}$, on W9: $+5.39 \mathrm{~kg}$, on W12: $+6.94 \mathrm{~kg}$ ). Selection for yearling weight would resulted in desirable correlated increase in all its components; birth weight increased by $0.09 \mathrm{~kg}$, body weight at 3,6 and 9 months of age increased by $0.83,2.66$ and $4.73 \mathrm{~kg}$, respectively. The direct genetic response in body weight at 12 months of age was higher than those reported by CHAKRAVARTY and RATHI (1989b) for Indian buffaloes (6.94 kg vs. $3.74 \mathrm{~kg})$. 
Selection for rapid rate of gain usually increases both birth weight and mature size. Increases in birth weight contribute to increased calving difficulty and subsequent perinatal death loss. Increased mature size increases the nutrient requirements for maintenance. In the present study all selection indexes showed that the increase in birth weight would not exceed $0.73 \mathrm{~kg}$, excluding any risk of dystocia (calving difficulty). This is contrary to the result of CHAKRAVARTY and RATHI (1989b) who found that selection on body weight at 12 months of age resulted in an increase by $+2.38 \mathrm{~kg}$ increase in birth weight in Indian buffaloes.

The maximum expected genetic gain in 12 month body weight was $8.85 \mathrm{~kg} /$ generation when all five body weights were included in the index; this decreased to $8.09 \mathrm{~kg} / \mathrm{generation}$ when body weights at birth, 3 and 6 months were excluded and further decreased to $6.94 \mathrm{~kg} /$ generation when selection based on yearling weight only. From the practical standpoint, selection on $\mathrm{I}_{5}$ involving body weight at 9 months of age can be considered as the best for improving yearling weight since its application is earlier, less expensive, higher accuracy than any index excluding yearling weight (Table 3 ) and giving reasonable amount $(+5.39 \mathrm{~kg})$ improvement in yearling weight (Table 4) as compared to direct selection (+6.94 kg).

Compared the growth curve when selection on the most accurate indexes $\left(I_{1}, I_{8}, I_{7}\right.$ and $\left.I_{5}\right)$ and the original one. The curves resulting from selection did not diverge from the original ones till month 3, after which the divergence increased progressively to reach its maximum at month 12 (Figure 2).

\section{References}

Alim KA (1991) Environmental and genetical effects on weights of calves in buffalo. World Rev Anim Prod 26, 83-7

Amin AA (2003) Test-day model of daily milk prediction across stages of lactation in Egyptian buffaloes. Arch Tierz 46, 35-45

Angulo R, Agudelo-Gómez D, Cerón-Muñoz MF, Jaramillo-Botero S (2006) Genetic parameters in buffalo calves fed at full milk in beef production system in middle Magdalena region of Colombia. Livest Res Rural Develop 18, 180, http://www.Irrd.org//rrd18/12/angu18180.htm [last accessed 02.07.2010]

Atil H, Khattab AS, Badawy L (2005) Genetic parameter of birth and weaning weights for Friesian calves by using an animal model. Arch Tierz 48, 261-9

Bhat PN (1992) Genetics of river buffaloes. In: Tulloh NM, Holmes JHG (eds.) Buffalo Production. World Anim Sci, C6. Elsevier, Amsterdam, Netherlands, 13-58

Bondoc OL, Salazar CD, Sarabia AS (1995) Correlations between body weights at different ages of water buffaloes. Proceedings of the 32 nd Annual Convention of PSAS 1, 273-83

Chakravarty AK, Rathi SS (1989a) Effect of genetic and non-genetic factors on growth, reproductive and production traits in Indian buffaloes. Asian J Dairy Res 8, 59-64

Chakravarty AK, Rathi SS (1989b) Direct and correlated genetic responses of some economic traits for selection of Indian buffaloes. Indian Vet J 66, 1124-7

Chakravarty AK, Rathi SS (1990a) Partial restriction selection indexes for genetic improvement of Indian buffaloes. Indian J Anim Sci 60, 1370-2

Chakravarty AK, Rathi SS (1990b) Use of secondary trait in unrestricted index selection of buffaloes. Indian J Dairy Sci 43, 28-31

Chakravarty AK, Rathi SS, Balaine DS (1991) Index selection for the genetic improvement of Indian buffaloes. Buffalo Bulletin 10, 89-91

Chantalakhana C, Skunmun P (1999) Log-term breeding strategies for genetic improvement of buffaloes in developing countries- review. Asian-Australasian J Anim Sci 12, 1152-61 
Cunningham EP, Mahou GAT (1977) SEIND: A Fortran Computer Program for Genetic Selection Indexes. An Foras Taluntais. Dunsinea. Castleknock, Co. Dublin and Dublin University, Ireland

Dahama RS, Malik PS (1989) Genetic analysis of body weights at different ages in buffaloes. Asian J Dairy Res $8,35-40$

Gurung B, Johar KS (1983) Genetic architecture of body weights in Murrah buffaloes. Indian Vet J 60, 365-70

Harvey WR (1990) LSMLMW. Mixed Least Squares and Maximum Likelihood Computer Program PC-2 Version. Dairy Science Department. The OH State Univ., Columbus, OH, USA

Khan MS, Hassan, F, Rehman MS, Hyder AU, Bajwa IR (2007) Genetic control of milk yield from lactations of different duration in Nili-Ravi buffaloes. Arch Tierz 50, 227-39

Kumar S, Yadav MC, Prasad RB (2008) Restricted selection index for genetic improvement in Indian buffaloes. Buffalo Bulletin 27, 233-5

Kumar V, Chaudhary SR, Rana ZS, Sangwan ML (1995) Genetic studies on the body weights of Murrah buffalo calves. Indian J Dairy Sci 48, 240-1

Mahdy AE, El-Shafie OM, Ayyat MS (1999) Genetic study and sire values for some economic traits in Egyptian buffaloes. Alexandria J Agricult Res 44, 15-35

Mourad, KA, Khattab, AS (2009) A comparison between different selection indices for some productive traits on Egyptian buffaloes. Arch Tierz 52, 476-84

Murdia CK, Chaudhary AL (1984) Genetic studies on body weights in light breeds of buffaloes. Indian J Anim Sci 54, 6-10

Preeti RT, Chakravarty AK (1999) Canonical correlation analysis for studying the association of breeding efficiency and expected producing ability with growth and reproductive traits of Murrah buffaloes. Indian J Dairy Sci 52, 284-8

Seno LO, Cardoso VL, Tonhati H (2006) Responses to selection for milk traits in dairy Buffaloes. Genet Mol Res 5, 790-6

Shahin KA, Shemeis AR, Abdallah OY, Saleh K (2000a) Effects of genetic control of subcutaneous fat disposition via using restricted selection indexes on live performance and carcass characteristics of Pekin duckling. Arch Tierz 43, 69-77

Shahin KA, Shemeis AR, Aabdallah OY, Saleh K (2000b) Selection index alternatives for increased marketing body weight with minimum concomitant reduction in body bone percentage recourse to tissue dissection on Japanese quail. Arch Tierz 43, 535-43

Shehu DM, Oni OO, Olorunju SAS (2008) Genetic ad phenotypic parameters for body weight of Sakoto Gudli (Bokoloji) cattle. Int J Pure Appl Sci 2, 64-7

Thevamanoharan K, Vandepitte W, Mohiuddin G, Chantalakhana C (2001) Restricted maximum likelihood animal model estimates of heritability for various growth traits and body measurements of swamp buffaloes. Pakistan J Agricult Sci 38, 19-22

Tien NQ, Tripathi VN (1990) Genetic parameters of body weight at different ages and first lactation traits in Murrah buffalo heifers. Indian Vet J 67, 821-5

Received 20 January 2009, accepted 19 January 2010.

Corresponding author:

KARIMA A. SHAHIN

email: shahin_ka@hotmail.com

Department of Animal Production, Faculty of Agriculture, Ain Shams University, P.O. Box 68, Hadayek Shoubra, 11241, Cairo, Egypt 